\title{
Szklary nickel deposit - a review and introduction to attempts in hydrometallurgical processing
}

\author{
Wojciech Kaczan ${ }^{1}$ (D) Jan Kudełko ${ }^{1}$ (D) $\cdot$ Herbert Wirth ${ }^{1}$ (D)
}

Received: 16 July 2020 / Accepted: 3 May 2021 / Published online: 12 May 2021

(C) The Author(s) 2021

\begin{abstract}
Szklary Massif is situated about $60 \mathrm{~km}$ from Wrocław (southwestern Poland) and around $7 \mathrm{~km}$ from Ząbkowice Śląskie. The history of raw materials in this region started in the fifteenth century with the discovery of precious minerals like chrysoprase, chalcedony, and opal. The exploitation of nickel ore in this region started in the nineteenth century and was conducted with few stops until 1983. The remaining $17.21 \mathrm{mln} \mathrm{mg}$ of ore with $125,000 \mathrm{mg}$ of nickel might be a chance to satisfy rising demand for raw materials used to develop electromobility. One of the crucial aspects regarding possible investment is the processing of ore. The pilot tests show the efficient use of heap leaching. The authors provide the future project in Szklary within the framework of circular economy.
\end{abstract}

Keywords Szklary $\cdot$ Nickel $\cdot$ Poland $\cdot$ Heap leaching $\cdot$ Zero waste $\cdot$ Circular economy

\section{Introduction}

The Szklary Massif is situated in southwestern Poland about $60 \mathrm{~km}$ south of Wrocław and about $7 \mathrm{~km}$ from Ząbkowice Ślaskie (Fig. 1). In morphological terms, it is a hill range expanding in a north-south direction. Parts of it are Wzgórze Siodłowe, Szklana Góra, Wzgórze Tomickie, Wzgórze Koźmickie. Geologically, it belongs to the Fore-Sudetic block and the Dislocation zone Niemcza (Niśkiewicz 1967).

Occurrences of nickel ores in Szklary are located within the elongated zone (Fig. 1). The central part was exploited from the XIX century until 1983 when the mine was closed. The decision was made due to the low grade of ore, inefficient processing technology, and the environmental aspects (Furmankiewicz and Krzyżanowski 2008). After the mine closure, the terrain was reclaimed and is currently covered with forest (Fig. 1). The processing waste (slag) remained as the tailing piles on the west side of Szklary (Fig. 1). In more recent times, the site was explored by two companies: KGHM

Wojciech Kaczan

wojciech.kaczan@pwr.edu.pl

1 Faculty of Geoengineering, Mining and Geology, Department of Mining and Geodesy, Wrocław University of Science and Technology, Wrocław, Poland
Polska Miedź S.A. and Gepco Geologia i Ochrona Środowiska, but their work did not result in the mine reopening. Nowadays, the region is not under exploration or mining concession. Only a tourist attraction exists in one of the remaining adits called "Robert" (Kaczan and Wirth 2020).

Recent economic interest in the nickel deposits were caused by the positive situation in the commodity markets and the increasing significance of this metal. The average price of nickel in recent years remains at a stable and high level. More than half of the recently produced nickel is consumed in the production of stainless steel (Wei et al. 2020). However, the rising demand for nickel, cobalt, lithium, and rare earths, mainly due to the development of battery production for electric vehicles is highly possible (Campagnol et al. 2017). It is assumed that the demand will result in the growing market price of nickel (Delevingne et al. 2020). Moreover, the latest critical raw material list for Europe refers to nickel as one of the significant metals in Europe's future (European Comission 2020).

The planning of mining investment needs special attention to environmental aspects (Wei et al. 2020). From the significant aspects, two are first to be met: a circular economy and a reduction of greenhouse gas emissions (Delevingne et al. 2020; Wei et al. 2020; European Comission 2019).

The article presents the current state of knowledge about Szklar. The description of the history and potential of the remaining parts of the deposit justifies the possibility of using 
Fig. 1 The current state of Szklary area (2019); red colour the simplified shape of the area of the deposits in Szklary (based on MIDAS 2020; GEOlog 2020); 1

- UAV photo - the northern part of the area; 2 - UAV photo - the southern part of the area

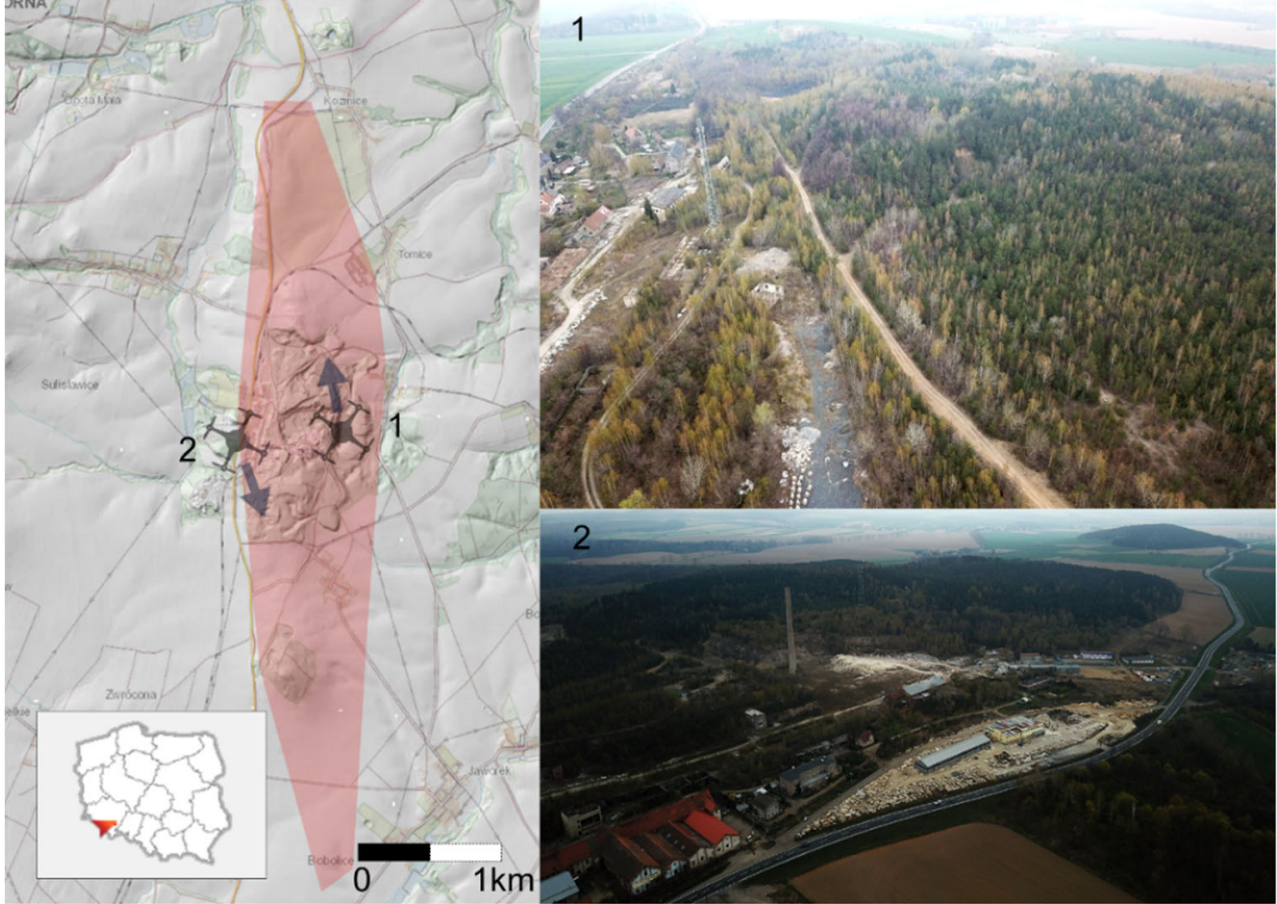

hydrometallurgy as an enrichment method suitable for this type of deposit. The authors present the results of preliminary research on this type of process. At the same time, leaching makes achieving reduced or zero waste management an attainable goal for a future mining project.

\section{History of Szklary}

The history of raw materials in Szklary started in the fifteenth century by the discovery of minerals like chrysoprase, chalcedony, and opal (Furmankiewicz and Krzyżanowski 2008). Therefore, the nickel ore was unknown until the nineteenth century. This nickel ore exploration was based on the analogy to the New Caledonian laterite nickel deposit. The exploitation of nickel started in the late nineteenth century. During the initial stage of mining, the subsurface ore contained 1$1.5 \% \mathrm{Ni}$, the deeper parts were recognised with an Ni content $2-4 \%$, and locally the ore even had $12 \% \mathrm{Ni}$. In the beginning, the ore was extracted only with an underground technique. From 1914 Zakłady Górniczo-Hutnicze Szklary (1974) or 1915 (Madej 2014; Żaba et al. 1991) parallel open-pit exploitation started which was better suited for the deposit form. Before and during the First World War, ore production was around 10,000 tonnes annually. In 1920, the activities were stopped for a few years due to the lack of economic ore. In 1934, mining was started once again because of the high nickel demand for military purposes related to the preparation for the Second World War (Furmankiewicz and Krzyżanowski 2008). During the war, ore production was around 100,000 tonnes. After the war, the site was destroyed and funds were needed for reconstruction. Within a few years, the exploitation was successfully re-started and the annual capacity was around 600 tonnes of nickel. At this time, it accounted for $0.3 \%$ of the world's nickel production (CIA 1954). After World War II, ore was only exploited with an open-pit method, which significantly resulted in a change of the region's morphology (Fig. 1). Ore was processed using the pyrometallurgical technique (Furmankiewicz and Krzyżanowski 2008). Between 1972 and 1977, it is reported that mine was also producing valuable chrysoprase. In 1972 1973, the production reached $2200 \mathrm{~kg}$ Zakłady GórniczoHutnicze Szklary (1974). In 1983, ore exploitation was stopped after Mill and Metallurgical Plant Szklary had been closed. The reason was the low amount of rich ores, the expensive enrichment process and the presence of asbestos in the dust. Since the closure, these deposits have not been exploited (Szuflicki et al. 2020; Niśkiewicz 2000; Fedak and Lindner 1966). After the closure, the fertilizer production plant was working on the site. This industry was closed in 1993.

Discontinuation of deposits' exploitation had several causes. One of the foremost were economic factors metal content in ore was too low, and pyrometallurgical processing was time-consuming, expensive, and ineffective. The other concern was the ecological factors. Asbestos, as occurring minerals in the ore, was of a high concern in the dust emissions, and was an argument for the closing of nickel ore exploitation and metallurgical processing (Wirth and Golczak 1987). 
After the closure in 1982 two significant exploration campaigns were conducted:

- KGHM Polska Miedź S.A. conducted an exploration campaign on the Szklary 1 field (the centre part of the Szklary area), based on a concession granted for 20062014. The works of KGHM were documented and are available in the PIG archives (Zielińska and Kobylańska 2011).

- GEPCO Geologia i ochrona środowiska, spółka z o.o. (the subsidiary of an Australian group - Northern Mining Limited) held two concessions. The first one was granted for the years 2007-2013 and the second for the years 2013-2014. Both concessions were withdrawn because of the failure to comply with the obligations. The main cause was that GEPCO did not conduct the geological works specified in the concession (NIK 2017; Northern Mining Limited, 2013; Northern Mining Limited, 2020).

Currently, within the close area of Szklary four neighbouring deposits are distinguished: Szklary 1, Szklary Szklana Góra, Szklary - Wzgórze Koźmickie, Szklary - Wzgórze Siodłowe (Table 1). The total measured resources are estimated to be 17.21 million tonnes of ore with 125,000 tonnes of nickel (cut-off grade equals $0.8 \%$ Ni) (Szuflicki et al. 2020; Mikulski 2012). In 2015, the criterion for nickel deposits in Poland has changed to cut-off grade $0.3 \%$. There is a need for the re-evaluation of the deposit using current cut-off grades. This will most probably result in increased resources (Mikulski and Sadłowska 2020; Journal of Law 2015).

\section{Geology of the Szklary deposit}

Szklary serpentinite massif is elongated according to the main tectonic directions of Dislocation Zone Niemcza (NorthSouth). However, it has a complicated shape due to its side branches and more recent tectonic deformations. There are two distinguished types of serpentinite: serpentinite and olivine serpentinite (Niśkiewicz 1967). Between them, there is a

Table 1 Resources of laterite nickel ore in Szklary, in thousands tonnes, cut-off grade $0.8 \% \mathrm{Ni}$ (based on Szuflicki et al. 2020)

\begin{tabular}{lll}
\hline Deposit name & Measured & Indicated \\
\hline Szklary 1 & 4371 & \\
Szklary-Szklana Góra & 6173 & 3033 \\
Szklary-Wzgórze Koźmickie & 1693 & 1086 \\
Szklary-Wzgórze Siodłowe & 4975 & 3322 \\
Total & 17,212 & 7441 \\
\hline
\end{tabular}

wide variety of transitional forms. Serpentinite appears in colors ranging from olive green to black with shades of green. The process of serpentinisation took place at a high temperature and with the presence of water (Madej 2014). There is a lack of regularity in the occurrence of particular serpentinite forms.

Vein rocks present in massif are substantially differentiated in terms of mineral composition and are represented by leucocratic (pegmatite and aplite veins) and melanocratic formations (cersanite and spessartite). Vein thickness ranges from over a dozen centimetres to a few metres (Niśkiewicz 1967). All of the massif's rocks are covered with in-situ weathered rocks and quaternary sediments. The contact rocks are gneisses (laminated, lenticular-eye, massive) amphibolites (lenticular-eye, massive), and occurring as inserts Mylonites and cataclasites (Niśkiewicz 1967; Kudełko and Wirth 2006).

Szklary Massif is covered with Pleistocene sediments. The thickness of them varies, and the highest reported equals $59 \mathrm{~m}$. Among Quaternary deposits, there can be silty and moraine clays, marginal type silts mudstones, sands, and gravels. Within the massif locally spotted can be rock exposures represented by older rocks such as serpentinites, granitoids, and gneisses (Niśkiewicz 1967).

The creation of the deposits in Szklary is connected to a warm and humid climate that occurred over 20 million years ago, at the turn of Oligocene and Miocene (Madej 2014). As a result of chemical weathering related to the activity of water containing carbon dioxide, serpentinite transformed into multicolored weathered rock cover with a thickness ranging from just a few metres up to $76 \mathrm{~m}$ (Niśkiewicz 2000). There were filled pockets, gutters, basins, and funnels in less weathered serpentinites (Żaba et al. 1991). Following the alteration of sediments, it has become enriched in nickel. Olivine was the main source of peridotites that afterward went through the serpentinisation process (Madej 2014).

During the exploitation in Szklary, geologists distinguished three main types of ore:

- Gray ore - hard to distinguish from the serpentinites but easier to exploit than serpentinites,

- Rusty-brown and red-brown ore - dusty and enriched in iron oxide,

- Green ore - occurs in small amounts, enriched in hydrated nickel silicates Plan ruchu (1967).

The main ore minerals are $\mathrm{Ni}$ silicates, which contain different contents of $\mathrm{Ni}$ and $\mathrm{Mg}$. Their occurrence varies vertically and is a result of the degree of weathering from top to bottom, with the magnesium content of the ore increasing and the iron content decreasing with higher weathering degree: 
- Schuchardite - green or yellow-green colour,

- Pimelite - light green color, occurs in the highly weathered rocks Plan ruchu (1967),

- Garnierite.

Other significant occurrences are:

- Ferrous minerals - mainly limonite and goethite,

- Silica - the valuable minerals: chalcedony, chrysoprase, opal,

- Magnesite - appears as a vein rock; the concentration of $\mathrm{MgO}$ in nickel ore equals around $15-17 \%$ Mikulski (2012).

Recognised accessory metals:

- Cobalt - reported content between 15 and 1536 ppm; average geometric mean $=119.6 \mathrm{ppm}$,

- Chromium - average content $0.23 \%$,

- Platinium - between 30 and 50 ppb Mikulski (2012).

\section{Nickel ore types}

Currently, the division into nickel class 1 and nickel class 2 is highlighted by investors. The main difference between these classes is based on the quality of the final product (Azevedo et al. 2020). In the case of class 2 nickel, there are products obtained like nickel pig iron (NPI) and ferronickel (FeNi) which have more contaminations and purity below $99.8 \%$ Ni. Class 1 nickel comprises nickel product with purity above $99.8 \%$ Ni. The class 2 nickel played a significant role in history as a component for stainless steel production and in alloys. Recently, the demand has been pushed into class 1 nickel, which suits the requirements for battery production (Campagnol et al. 2017).

World production of nickel is based on two main nickel-ore types:

- Sulfides - where the principal ore mineral is pentlandite (USGS 2020). These deposits are formed by fractional crystallisation within magma chambers or in ancient lava flows. The ore grades range from 0.15 to around $8 \%$, but $93 \%$ of known deposits are in the range of $0.2-2 \% \mathrm{Ni}$ (BGS 2008).

- Laterites - where the main nickeliferous minerals are limonite and garnierite (USGS, 2020). They are formed by tropical and subtropical surface weathering. The average ore grades vary between 1 and $1.6 \% \mathrm{Ni}$ (BGS, 2008). The typical laterite ore consists of bedrock (serpentinite), rocky ore with boulders (saprolite), earthy ore (transition), yellow limonite ore, red limonite ore, and cuirass (Fig. 2).
The research into possible hydrometallurgical processing - heap leaching

The choice of processing technology is determined by the characteristics of the laterite deposit (Fig. 2). The main directions are:

- Hydrometallurgical processes like the Caron process*, high-pressure acid leaching, AMAX process, atmospheric leaching, and heap leaching can be applied mainly for red limonite, yellow limonite, transition ore, and partly saprolite/garnierite/serpentine ore.

- Pyrometallurgical processes like ferronickel smelting, matte smelting, and blast/electric furnace for bedrock, transition ore, and partly the deepest yellow limonite ores (Elias 2013).

*Elias (2013) described that the caron process mainly suits yellow limonite and transition ores (Fig. 2)

Szklary's ore was processed with the pyrometallurgical technique throughout its entire history of mining activity. Considering the recent BAT in laterite ore processing mentioned above, the best-suited technology for Szklary deposit are hydrometallurgical methods. The Caron process lacks efficient cobalt recovery (Elias 2013), which might be an issue in Szklary. It leads to the conclusion that acid leaching, and more specifically heap leaching seems both in a technical and economic sense, the most attractive for the Szklary deposit also.

The primary research about the alternative methods of metallurgical and hydrometallurgical nickel extraction from poor ores $(0.7-0.8 \% \mathrm{Ni})$ and metallurgical slags $(0,25 \% \mathrm{Ni})$ emerging from ferronickel production waste, was conducted between the 1960's and 1980's. The research took place at Wrocław University of Technology Projekt...(2005).

After 2000, the research was continued by KGHM Cuprum due to the rapid growth of nickel prices. As a consequence, the proposed technology was to use the leaching with a sulphuric acid as a leaching agent, because it has all the necessary characteristics. It is effective, cheap, easily accessible, non-toxic and does not require regeneration. The mentioned research was discontinued, mainly due to the strategic importance of sulphuric acid used in the chemical industry and the lower nickel prices.

The main assumption was to divide ore to the two different streams for acid leaching (Fig. 3):

- ore with a high nickel content crushed to a fine fraction and then placed in the reactor,

- ore with a smaller nickel content crushed to a coarse fraction, placed on a heap and leached. Due to the inefficient precipitation (Fig. 4), after the first leaching the ore should be crushed again and leached. 
Fig. 2 Schematic laterite profile (Elias 2002)

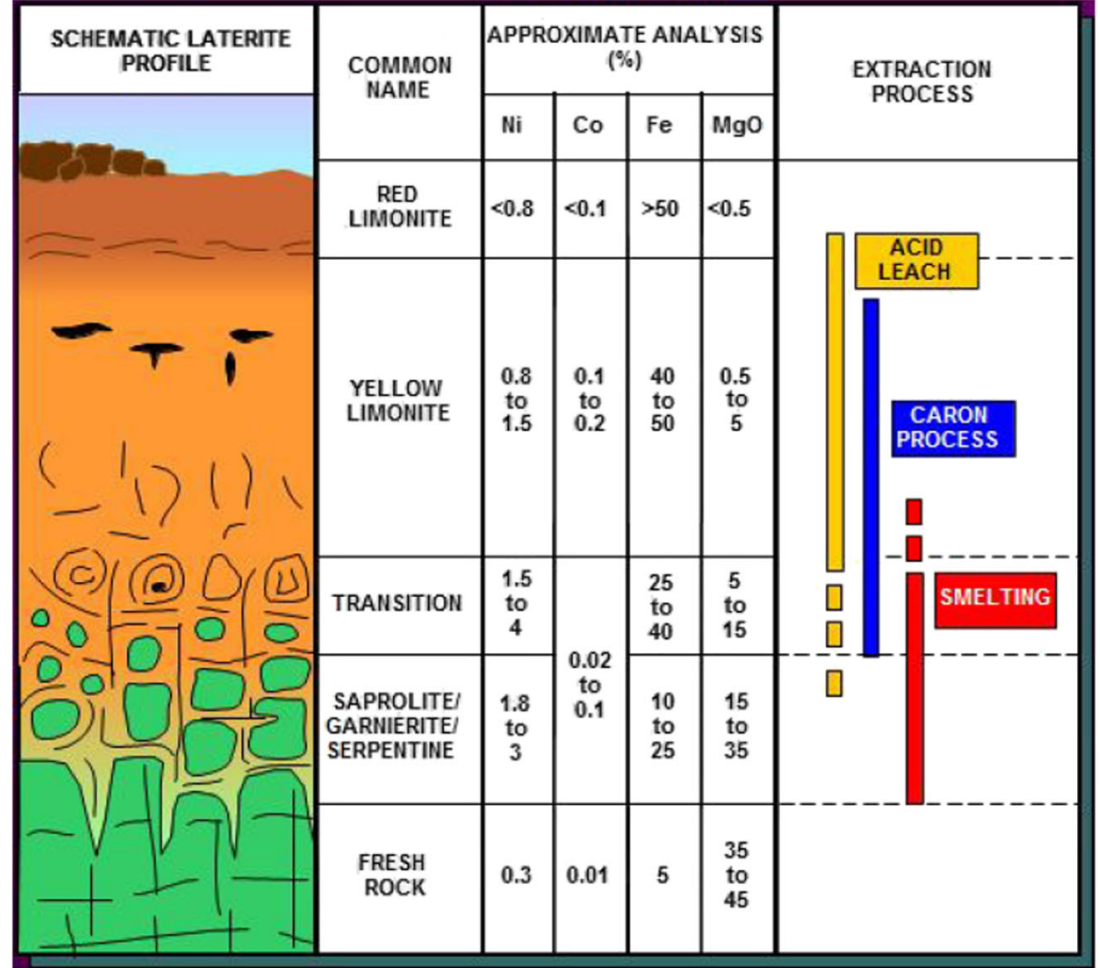

The main advantage of this technology is the possibility of simultanous recovery of $\mathrm{Ni}(\mathrm{OH})_{2}, \mathrm{FeOOH}, \mathrm{Mg}(\mathrm{OH})$, $\mathrm{MgSO}_{4} \cdot \mathrm{H}_{2} \mathrm{O}$, and the other elements like $\mathrm{Co}, \mathrm{Mn}, \mathrm{Cr}$. The nickel hydroxide concentrate can be used directly in the stainless steel production or further processed to obtain cleaner metal products. The expected recovery rate for nickel is $86 \%$, as it was achieved with the heap leaching process for analogical ores in Greece.
Fig. 3 Simplified technological line proposed for the processing of Szklary nickel ore

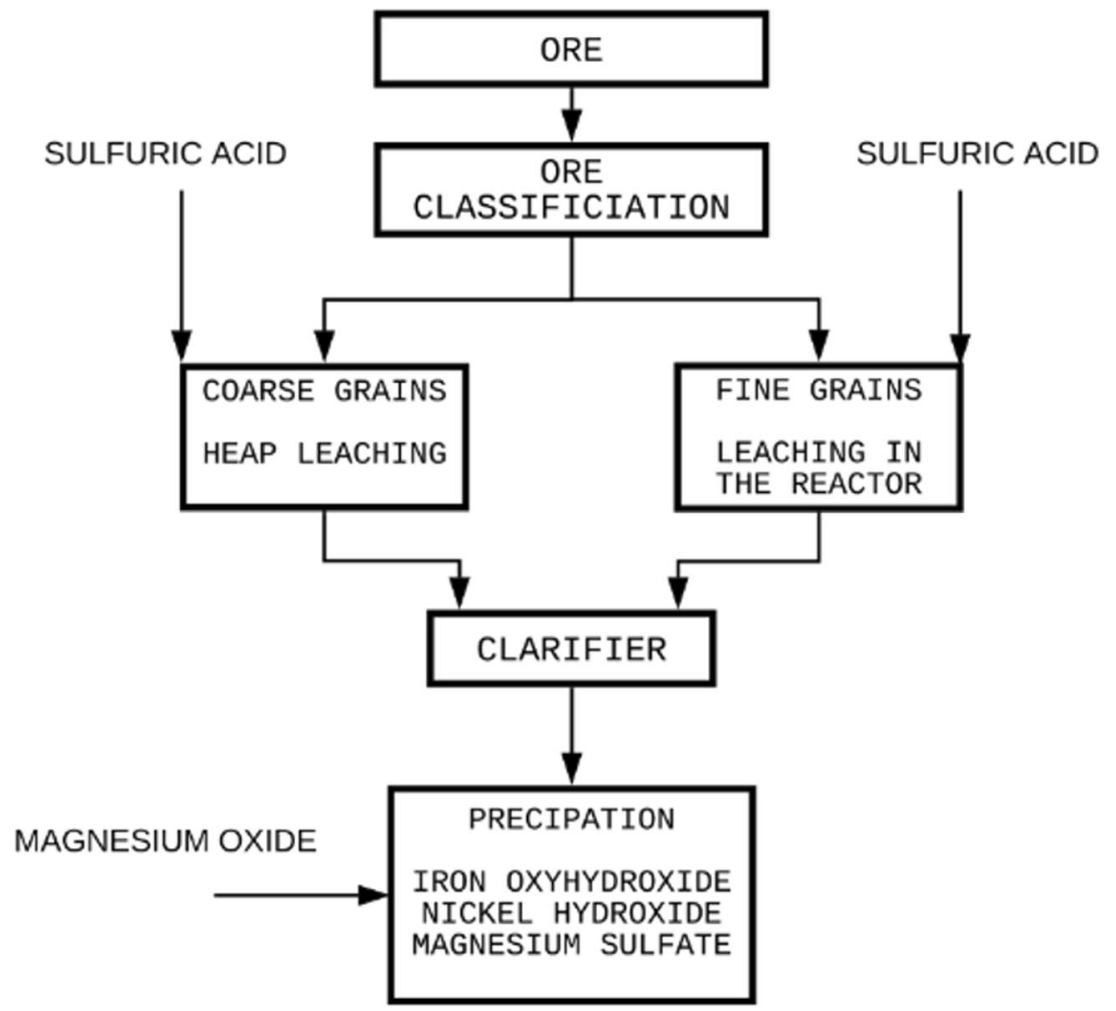




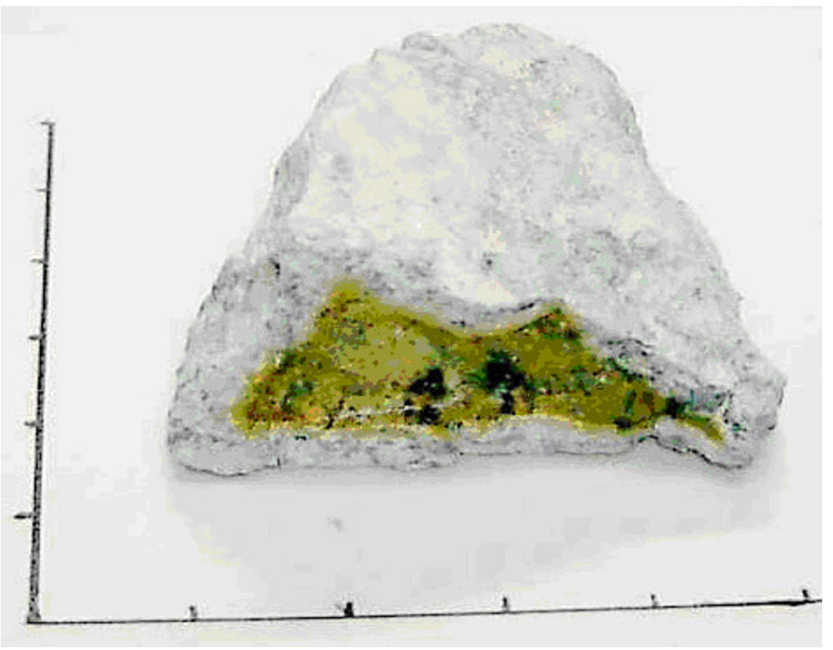

Fig. 4 The result of heap leaching of Szklary ore - a coarse fraction (5 $\mathrm{cm}$ ), visible boundary between the leached and un-leached ore

In an analysis and estimation of each hydrometallurgical technology, these aspects have to be taken into account:

1. Technical - amount of resources, composition, mineralogy, selection of a leaching agent, the efficacy of leaching of useful ingredients, time of leaching, unit operation parameters, shape and quality of a product, essential tools, etc.,

2. Economic - capital and operational costs,

3. Ecological - the process has to abide by environmental protection standards in both solid and liquid waste, means of its utilisation and its storage or exploitation, with a highlighted significance in the reduction of asbestos emissions.

Due to the insufficient amount of information, both in terms of assessing the size of the deposit, the composition and suitability of the ore for the proposed hydrometallurgical technology, as well as the parameters of unit processes (ore leaching, separating metals in solution and isolating products), it is hard to determine its use without further testing.

\section{A circular economy - is it possible in Szklary? Current challenges}

A circular economy was introduced as the economic system that replaces the old "end-of-life" concept, with reducing, alternatively reusing, recycling and recovering materials in production/distribution and consumption processes. It operates at the micro (products, companies, consumers), meso (eco-industrial parks) and macro level (city, regional, national, global), with the aim of accomplishing sustainable development, thus simultaneously creating environmental quality, economic prosperity and social equity, to the benefit of current and future generations Kirchherr et al. (2017).

Considering Szklary as a potential mining project, we suggest that the planning from the very beginning should be adjusted to the circular economy rules. This approach is getting more and more attention in science Kaczan and Wirth (2020) in industry Delevingne et al. (2020) and at the political level (European Comission 2019). In the case of Szklary, we also suggest that there is a potential of close-to-zero waste production at each mining project step (Fig. 5).

The first step is prospecting and exploration. This step when properly conducted allows for optimisation of the extraction and processing. As mentioned before, the exploration of Szklary deposits was already conducted historically and more recently by KGHM and Gepco. However, further works are required, especially in the non-central parts (marginal parts of the deposit - Wzgórze Siodłowe and Wzgórze Koźmickie). Exploration and analyses should lead to having wider knowledge about the content of accessory minerals and elements (Cwojdziński et al. 2008; Mikulski 2012; Mikulski and Sadłowska 2015).

The second phase (extraction), is proposed to be conducted by the slope open-cast method. This idea was proposed by Zielińska and Kobylańska (2011). However, the initial plan of having dispersed open-pits only in the enriched zones appears to not be reasonable because of the complex character of the deposit. The better solution could be one open-pit with one or two floors. The second important issue is the presence of asbestos. Because of this, the dusting occurring during extraction should be limited to zero. Throughout the world the solution for that issue is the use of sprinkling. The authors also

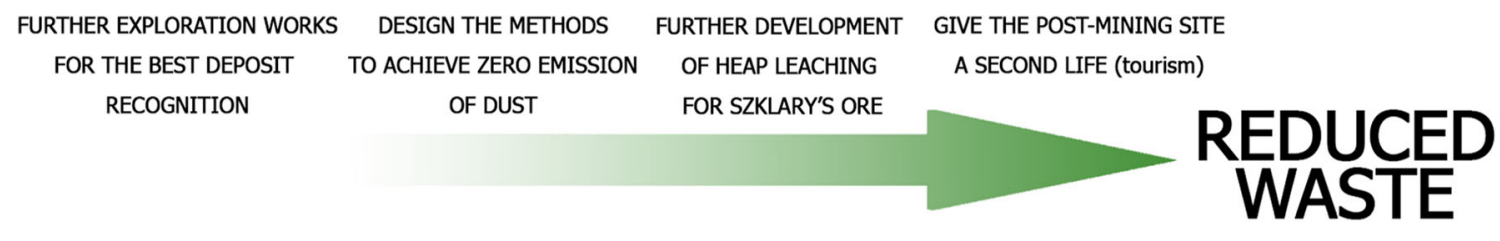

\section{EXPLORATION EXTRACTION PROCESSING RECLAMATION}

Fig. 5 Challenges in the planning of mining investment in Szklary to achieve circular economy 


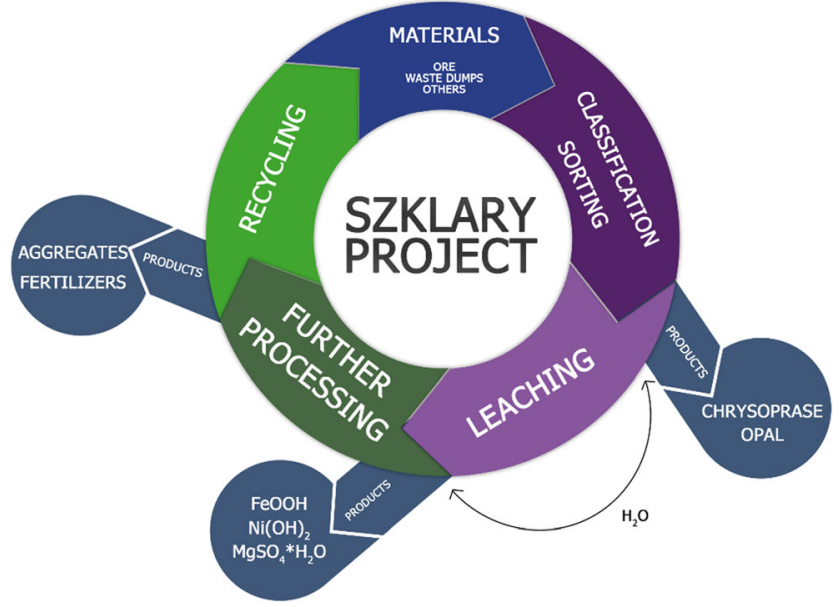

Fig. 6 The idea for the circular economy project in Szklary

suggest considering the possibility of creating a cupola covering the exploited fragment of the deposit. Gathered hazardous dust could also be neutralised and reused; however, the research in this matter was not conducted on the Szklary's ore.

The crucial waste generating step is the processing. The general framework for the circular economy Szklary project is to fully use ore (Fig. 6). The first products should be minerals like chrysoprase, chalcedony and opal, which are valuable in the economical sense. The tested hydrometallurgical processing leads to obtaining nickel hydroxide, magnesium sulfate, and iron oxide-hydroxide. This leads to the conclusion that the most significant metals in the ore will be extracted. Authors also point out to the significant role of water in mining projects, especially for Szklary, where the water was intensively used in the past. The historical mining led to the changes in the natural hydrological situation Chudy and Worsa-Kozak (2013). The possible solution is to apply retention of water during the process (Fig. 6).

A significant aspect in the holistic consideration is the social impact. The large-scale investment could boost the development of the described region. The mining activity provides revenues for the local government and workplaces for society. After the process, there are possible many reclamation directions (motorcycle roads, walking paths, parks) which will provide the opportunities to develop tourism and recreation sites.

\section{Summary}

Considering the current research conducted on the extraction of nickel and cobalt from small deposits with similar properties to ores from the Szklary region, recovery of these metals with hydrometalurgy is technically feasible using the sulfuric acid leaching method.
Promising results of research into the possibility of obtaining nickel from Szklary deposits affects the legitimacy of considerations on the resumption of exploitation of this ore. The increasing demand for modern technologies - in particular, those related to electromobility drives the raw materials market.

To make any strategic decision regarding the launch of the project, it is necessary to take into account economic and environmental aspects. All materials obtained should have product hallmarks. The results of preliminary analyses also show that it is possible to achieve a circular economy objectives.

The condition for making a decision to implement a project should be a satisfactory assessment of its economic effectiveness. Due to the lack of complete information, such an assessment of the presented project cannot be made at this stage. The complexity of decisions makes it an issue that requires many problems to be solved. They concern the selection of assessment methods appropriate to the decision-making situation, determined by the specificity of the project, the investor's needs and expectations, and decision-making conditions. Before deciding to implement a project, it is necessary to check whether the related cash expenses may pose a threat to the effective economic operation of the enterprise. The application of a given method and a given evaluation criterion requires an analysis of the project's features and appropriate arrangements with the future investor.

Data and materials availability Used data is accessible in the cited references

Code availability Not applicable

Funding Budżet Podstawowy - PODST_BAD_EXP (8201003902)

\section{Declarations}

\section{Conflict of interest Not applicable}

Open Access This article is licensed under a Creative Commons Attribution 4.0 International License, which permits use, sharing, adaptation, distribution and reproduction in any medium or format, as long as you give appropriate credit to the original author(s) and the source, provide a link to the Creative Commons licence, and indicate if changes were made. The images or other third party material in this article are included in the article's Creative Commons licence, unless indicated otherwise in a credit line to the material. If material is not included in the article's Creative Commons licence and your intended use is not permitted by statutory regulation or exceeds the permitted use, you will need to obtain permission directly from the copyright holder. To view a copy of this licence, visit http://creativecommons.org/licenses/by/4.0/. 


\section{References}

Agatzini-Leonardou S, Dimaki D (1994) Heap Leaching of Poor Nickel Laterites by Sulphuric Acid at Ambient Temperatures. In: Hydrometallurgy '94, volume 1. Chapman \& Hall, London, pp 193-208

Azevedo M, Goffaux N, Hoffman K (2020) How Clean Can the Nickel Industry Become? Insights, McKinsey

British Geological Survey (BGS) (2008) Nicel - mineral profile. www. mineralsuk.com

Campagnol N, Hoffman K, Lala A, Ramsbottom O (2017) The Future of Nickel: A Class Act. McKinsey Insights

Chudy K, Worsa-Kozak M (2013) Zmiana warunków hydrogeologicznych w rejonach dawnej eksploatacji górniczej na przykładzie Masywu Szklar, Dzieje górnictwa, 5

CIA (1954) Nickel supply in the soviet bloc, Provisional Intelligence Report: 449280

Cwojdziński S, Nieć M, Bossowski A, Michniewicz M, Mikulski S, Mochnacka K, Mydłowski A (2008) Ocena Perspektyw Występowania Złóż Rud Metali w Sudetach i Na Bloku Przedsudeckim w Nawiązaniu Do Aktualnych Modeli Geotektonicznych. Wrocław: PIG

Delevingne L, Glazener W, Grégoir L, Henderson K (2020) Climate Risk and Decarbonization: What Every Mining CEO Needs to Know. McKinsey Insights

Elias M (2002) Nickel laterite deposits - geological overview, resources and exploitation. In Giant Ore Deposits: Characteristics, genesis and exploration. CODES Special Publication 4, Centre for Ore Deposit Research, University of Tasmania

Elias M (2013) Nickel Laterites in SE Asia - Geology, Technology and Economics - Finding the balance. East Asia: Geology, Exploration Technologies and Mines, Bali

European Comission (2019) Development of a Guidance Document on Best Practices in the Extractive Waste Management Plans Circular Economy Action. https://doi.org/10.2779/061825

European Comission (2020) Communication from the Comission to the European Parliament, the Council, the European Economic and Social Committee and the Committee of the Regions. Critical Raw Materials Resilience: Charting a Path towards Greater Security and Sustainability. Brussels. https://doi.org/10.1007/978-3-030-4026869

Fedak J, Lindner M (1966) Metalogeneza Sudetów. Warszawa: Wydawnictwa Geologiczne

Furmankiewicz M, Krzyżanowski K (2008) Podziemne Relikty Kopalni Niklu w Szklarach. Dzieje Górnictwa - Element Europejskiego Dziedzictwa Kultury I: 51-60

GEOlog (2020) An interactive map of Poland. Accessed 25 December. http://geolog.pgi.gov.pl

Journal of Law (2015) Position 987, Rozporzadzenie Ministra Środowiska z dnia 1 lipca 2015 r. w sprawie dokumentacji geologicznej złoża kopaliny, z wyłączeniem złoża węglowodorów

Kaczan W, Wirth H (2020) Preliminary Analysis of Szklary Deposit (SW Poland) in the Aspect of Critical Metals Occurrence with Respect to the Circular Economy. AIP Conference Proceedings 2209. https:// doi.org/10.1063/5.0000010.

Kirchherr J, Reike D, Hekkert M (2017) Conceptualizing the circular economy: an analysis of 114 definitions. Resour Conserv Recycl 127:221-232
Kudełko J, Wirth H (2006) Weryfikacja bazy zasobowej złóż rud laterytowych "Szklary" pod kątem zastosowania procesu hydrometalurgicznego do ekstrakcji niklu. Czasopismo Techniczne 128:30-38

Madej S (2014) Opis Geostanowiska - Szklary. Geopark Wzgórza Niemczańsko-Strzelińskie

MIDAS (2020) Database of Documented Deposits. Accessed 25 December. http://geoportal.pgi.gov.pl/midas-web/

Mikulski SZ (2012) Występowanie i zasoby perspektywiczne rud niklu w Polsce. Biuletyn Państwowego Instytutu Geologicznego 448(2): 287-296

Mikulski SZ, Sadłowska K (2015) Mapy obszarów perspektywicznych wystapień rud metali w. Polsce w skali $1: 200000$ - rudy niklu typu wietrzeniowego ( saprolitowego ) na bloku przedsudeckim ( SW Polska )' 63(9):556-560

Mikulski SZ, Sadłowska (2020) Rudy niklu. In Bilans perspektywicznych zasobów kopalin Polski

Najwyższa Izba Kontroli (NIK) Delegatura w Opolu (2017) Wystapienie Pokontrolne, LOP.410.007.05.2017, P/17/015

Niśkiewicz J (1967) Budowa Geologiczna Masywu Szklar (Dolny Ślask). Rocznik Polskiego Towarzystwa Geologicznego XXXVII 3

Niśkiewicz J (2000) Pokrywa zwietrzelinowa masywu Szklar i jej niklonośność [The Szklary massif nickel-bearing weathering cover]. Geol Sudet 33(2):107-130

Northern Mining Limited (2013) Szklary Ni Project - Mining Concession Renewal, http://www.northernmining.com.au/investor/ announcements/2013/mining-concession-renewal-szklary-niproject

Northern Mining Limited (2020) Consolidated Financial Statement for the year ended 30. http://www.northernmining.com.au/investor/ announcements/2020/annual-report-2020

Plan ruchu Zakładu Górniczo-Hutniczego Szklary (1967) Unpublished, Szklary

Projekt geologicznych prac badawczych na obszarze złoża rud niklu Szklary I (2005) Unpublished, Wrocław

Rozporządzenie Ministra Środowiska (2001) z dn. 19.12 r. - w sprawie projektów prac geologicznych (Dz.U. nr 153 poz. 1777)

Szuflicki M, Malon A, Tymiński M (2020) Bilans zasobów złóż kopalin w Polsce wg stanu na 31 XII 2019 r. Warszawa

United States Geological Survey (USGS) (2020) Nickel statistic and information. https://www.usgs.gov/centers/nmic/nickel-statistics-andinformation

Wei W, Samuelsson PB, Tilliander A, Gyllenram R, Jönsson PG (2020) Energy consumption and greenhouse gas emissions of nickel products. Energies 13:5664. https://doi.org/10.3390/en13215664

Wirth H, Golczak I (1987) Dodatek nr 3 do dokumentacji geologicznej złoża rud niklu "Szklary" obszar Wzgórze Siodłowe w kat. B+C ${ }_{1}$. Arch. PG, Wrocław

Żaba J, Janeczek J, Kozłowski K (1991) Wycieczka 4. in Zbieramy Skały i Minerały, 78-85. Warszawa: Wydawnictwo Geologiczne

Zakłady Górniczo-Hutnicze Szklary (1974) Zarys historii i rozwoju zakładów górniczo-hutniczych w Szklarach. Szklary

Zielińska A, Kobylańska M (2011) Geologiczne uwarunkowania eksploatacji złoża rud niklu "Szklary 1"”. Górnictwo Odkrywkowe 52(1-1):60-66

Publisher's note Springer Nature remains neutral with regard to jurisdictional claims in published maps and institutional affiliations. 